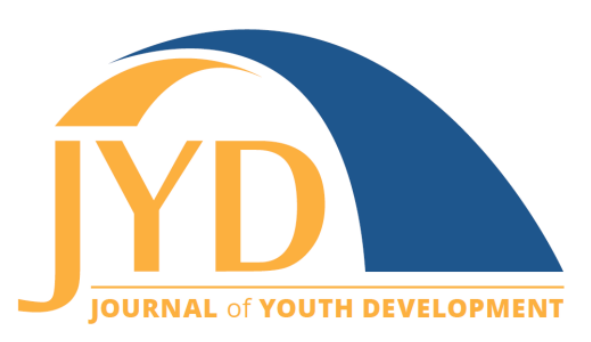

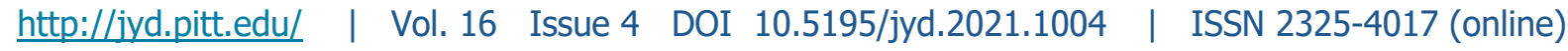

\title{
4-H Youth Volunteer Retention in Science Projects
}

\author{
Veronica Del Bianco \\ Louisiana State University, Agricultural and Extension Education and Evaluation \\ veronica.delbianco@umces.edu \\ Melissa Cater \\ Louisiana State University, Agricultural and Extension Education and Evaluation \\ mcater@agcenter.Isu.edu
}

\section{Janet Fox}

University of Tennessee Extension Institute of Agriculture

jfox35@utk.edu

\begin{abstract}
Retention of volunteers and participants is a critical concern for programs that rely on their manpower, but limited empirical research exists, especially on youth volunteers. This descriptive, cross-sectional quantitative study examined the influence of volunteer motivation, participation, and science project type on the retention of 4-H youth volunteers ages 12 to 19 years participating in science projects in 3 states. An instrument was created for this study that included both existing survey scales and researcherdeveloped items based on combined research from the citizen science, volunteer development, and youth development fields. The research revealed that consistency and engagement were correlated with the predictors of retention, but race was not. 4-H science programs have a significantly higher likelihood of retaining youth participants than 4-H citizen science programs. Suggestions for youth educators to develop retention strategies are discussed based on the findings and future research into youth volunteer engagement is proposed.
\end{abstract}

Key words: youth volunteers, retention, citizen science, science, engagement

Citizen science is emerging as a valuable research approach for scientific discovery (Follett \& Strezov, 2015). It enables researchers to look at large-scale patterns in nature, space, and even amino acids (Bonney et al., 2009; Curtis, 2015; Raddick et al., 2009). Unlike other research techniques, citizen science relies heavily on volunteers of all ages in the general public to participate in the scientific research process. This component of contribution to generating new knowledge is what sets citizen science apart from other educational science projects where

(cc) EY New articles in this journal are licensed under a Creative Commons Attribution 4.0 License. This journal is published by the University Library System, University of Pittsburgh and is cosponsored by the University of Pittsburgh Press. The Journal of Youth Development is the official peer-reviewed publication of the National Association of Extension 4-H Youth Development Professionals and the National AfterSchool Association. 


\section{4-H Youth Volunteer Retention in Science Projects}

participants merely perform and practice the scientific process. Yet, adult volunteer attrition rates in three citizen science programs were estimated between 80 to $95 \%$ (Rotman et al., 2014) and there is no data on youth volunteer retention. This study explores the critical issue of youth volunteer retention in science and citizen science projects.

\section{Review of Literature}

Despite retention being identified as a key concern, limited empirical research on volunteer retention exists (Newton et al., 2014). A systematic review of the literature revealed only six articles focused on citizen science volunteer retention: Crimmins et al. (2014); Frensley et al. (2017); Martin et al.(2016); Seymour \& Haklay (2017); van der Wal et al. (2016); and West and Pateman (2016). Increased mobility and feedback from scientists have been found to be predictors of retention in adult citizen science volunteers (Crimmins et al., 2014; Martin et al., 2016; Seymour \& Haklay, 2017; van der Wal et al., 2016) and may be transferable to youth.

Youth volunteer retention in citizen science programs has not been studied. However, a study examining young adults' environmental volunteerism, found that those motivated to volunteer for social reasons were more likely to invest greater amounts of time in volunteering than individuals with other motivations (McDougle et al., 2011). Demographic variables such as gender, race, and ethnicity have also been shown to be predictors of volunteer participation and youth participation in organized activities (Bohnert et al., 2010; Mahoney et al., 2009). The question remains: are they predictors of retention?

\section{Conceptual Framework}

In a literature review of research on youth involvement in organized activities, Bohnert et al. (2010) proposed a conceptual model of participation in organized activities (OA; see Figure 1). This framework was utilized in this study.

While many previous studies have looked at the intrinsic and extrinsic motivations of citizen science project volunteers, this study takes a functional approach to motivation, focusing on "the personal and social functions being served by an individual's thoughts, feelings, and actions (Snyder, 1993)" (Clary et al., 1998, p. 1517). The Volunteer Functions Inventory (VFI) describes six functions potentially served by involvement in volunteer activities: values, understanding, social, career, protective, and enhancement. 


\section{Figure 1. The Conceptual Model of Participation in Organized Activities}

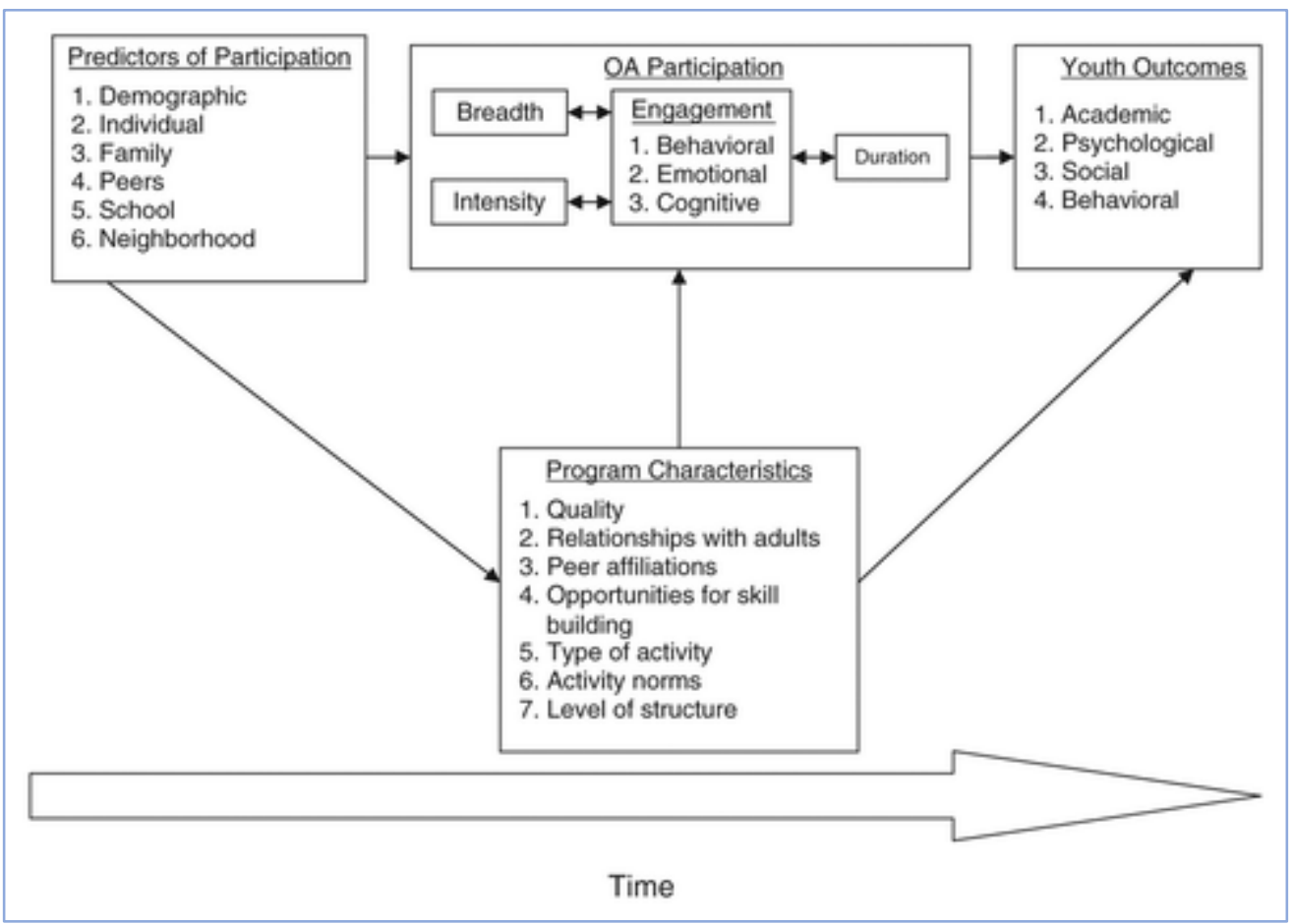

Note. Proposed by Bohnert et al. (2010, p. 579). Reprinted with permission.

Measuring retention, particularly in a cross-sectional study, is difficult. Research in human resource management has shown that intention to stay and the affective component of organizational commitment-an individual's "emotional attachment to, identification with and involvement in, the organization" (Allen \& Meyer, 1990, p.1)-are predictors of retention in employees. These two indicators of retention have been adapted by the volunteer literature (Newton et al., 2014) and were utilized in this study to measure the retention of 4-H youth volunteers in science projects.

\section{Purpose and Objectives}

The primary purpose of this study is to determine if relationships exists between volunteer motivation, participation, and science project type and retention of 4-H youth ages 12 to 19 years participating in science projects (see Figure 2). 


\section{Research Questions}

1. What are 4-H participants' attitudes towards science programs in terms of retention as measured by affective commitment (AC) and intention to continue volunteering (ICV)?

2. Is there a relationship between 4-H participants' volunteer motivation measured by score on VFI and retention in science projects?

3. Is there a relationship between 4-H youth's participation in science projects as measured by engagement, duration, consistency, intensity, and dosage and retention?

4. What differences in retention exist between participants based on gender, race/ethnicity, and science program characteristics?

Figure 2. Hypothesized Correlations between the Variables as Outlined in this Study

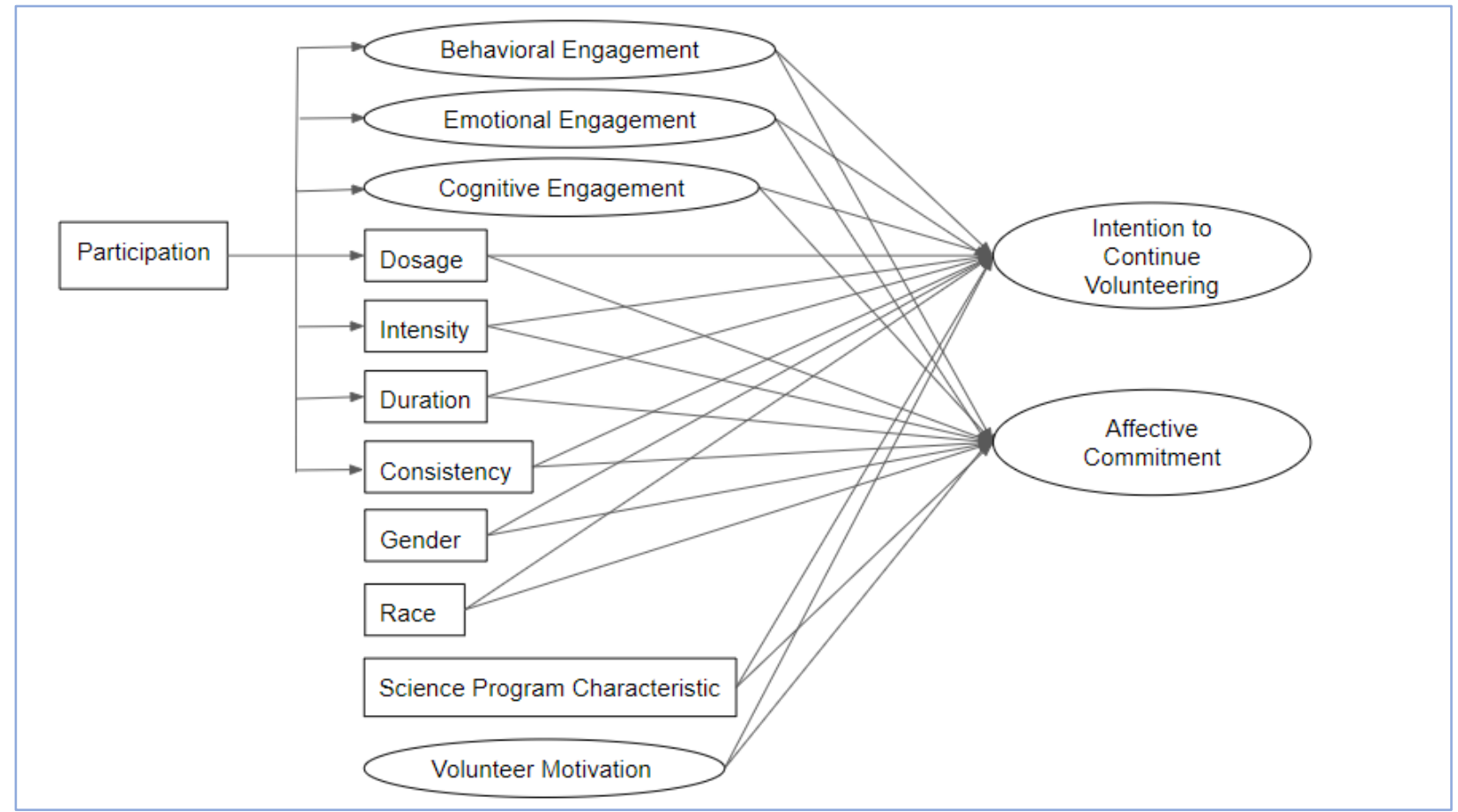

\section{Methods}

\section{Population and Sample}

The target population was 4-H participants between the ages of 12 and 19 years who were participating in citizen science programs. The accessible population was identified by 4-H professionals and through social media with hashtags \#citizenscience, \#science, \#STEM and \#4H. In total, 180 4-H youth from Louisiana, Tennessee, and Virginia participated in the study 


\section{4-H Youth Volunteer Retention in Science Projects}

and 177 completed all the measures pertaining to retention. The mean age was of participants was 12.73 years old ( $S D=1.66 ; N=169$ ) with a range of 8 to 18 years old. Gender was split with 93 boys (52.5\%), 84 girls (47.5\%), and three no responses. The racial and ethnic distribution of the $4-\mathrm{H}$ youth participants included $47.2 \%$ White $(n=83), 23.9 \%$ Black or African American ( $n=42) 16.5 \%$ multiracial $(n=29), 10.2 \%$ Hispanic or Latino $(n=18), 1.1 \%$ American Indian or Alaska Native $(n=2)$ and $1.1 \%$ Asian $(n=2)$. Four individuals did not report race/ethnicity. Of the 180 respondents in the study, 132 (73.3\%) participated in 4-H science programs and 48 (26.7\%) participated in 4-H citizen science programs.

\section{Instrument}

Scales related to volunteer engagement, retention, and motivation were located in the survey; their descriptions can be found in Table 1. Scoring for all three subscales of engagement, both retention measures, and all six subscales of motivation were calculated mean scores (see Table 1). The majority of these scales have reported internal consistency from previous studies: Cronbach's alpha for the behavioral, emotional, and cognitive engagement subscales ranged from .67 to $.95, .79$ to .84 , and .60 to .90 , respectively (Champine \& Johnson, 2017; Li \& Lerner, 2013). Cronbach's alpha for the affective commitment scale ranged from .806 to .872 (Eisinga et al., 2010). A systematic review of the VFI discovered eight studies that provided data on Cronbach's alpha for the total scale with a mean internal consistency of .90, and a range between .83 and .94 (Chacón et al., 2017). 
Journal of Youth Development | http://jyd.pitt.edu/ | Vol. 16 Issue 4 DOI 10.5195/jyd.2021.1004 4-H Youth Volunteer Retention in Science Projects

Table 1. Instrument Engagement, Retention, and Motivation Measures

\begin{tabular}{|c|c|c|c|c|}
\hline $\begin{array}{l}\text { Main } \\
\text { dimension }\end{array}$ & $\begin{array}{l}\text { Instrument } \\
\text { measures }\end{array}$ & $\begin{array}{l}\text { Number } \\
\text { of items }\end{array}$ & $\begin{array}{l}\text { Measure definition with } \\
\text { example item }\end{array}$ & Response \\
\hline \multirow{3}{*}{ Engagement } & $\begin{array}{l}\text { Behavioral } \\
\text { engagement }\end{array}$ & 5 & $\begin{array}{l}\text { Active participation and frequency } \\
\text { of certain behaviors: "How often } \\
\text { do you . . . complete tasks on } \\
\text { time?" }\end{array}$ & $\begin{array}{l}\text { never } \\
\text { sometimes } \\
\text { often } \\
\text { always }\end{array}$ \\
\hline & $\begin{array}{l}\text { Emotional } \\
\text { engagement }\end{array}$ & 5 & $\begin{array}{l}\text { The extent to which one } \\
\text { experiences positive } \\
\text { and negative reactions to teachers, } \\
\text { peers, and activities: "I feel a part } \\
\text { of my program" }\end{array}$ & $\begin{array}{l}\text { strongly disagree } \\
\text { disagree } \\
\text { agree } \\
\text { strongly agree }\end{array}$ \\
\hline & $\begin{array}{l}\text { Cognitive } \\
\text { engagement }\end{array}$ & 5 & $\begin{array}{l}\text { Investment in learning: "I want to } \\
\text { learn as much as I can in the } \\
\text { program." }\end{array}$ & $\begin{array}{l}\text { strongly disagree } \\
\text { disagree } \\
\text { agree } \\
\text { strongly agree }\end{array}$ \\
\hline \multirow{2}{*}{ Retention } & $\begin{array}{l}\text { Intention to } \\
\text { continue } \\
\text { volunteering }\end{array}$ & 5 & $\begin{array}{l}\text { "I will continue to volunteer in the } \\
\text { citizen science project at least once } \\
\text { a month for the next } 12 \text { months." }\end{array}$ & $\begin{array}{l}\text { strongly disagree } \\
\text { disagree } \\
\text { agree } \\
\text { strongly agree }\end{array}$ \\
\hline & $\begin{array}{l}\text { Affective } \\
\text { commitment } \\
\text { scale }\end{array}$ & 4 & $\begin{array}{l}\text { Psychological state that binds the } \\
\text { individual to the organization: "I } \\
\text { feel a strong sense of belonging to } \\
\text { my program." }\end{array}$ & $\begin{array}{l}\text { totally disagree to } \\
\text { totally agree }\end{array}$ \\
\hline $\begin{array}{l}\text { Volunteer } \\
\text { motivation }\end{array}$ & $\begin{array}{l}\text { Volunteer } \\
\text { functions } \\
\text { inventory }\end{array}$ & $\begin{array}{l}5 \text { items } \\
\text { per } 6 \\
\text { functions } \\
\text { for a total } \\
\text { of } 30 \\
\text { items }\end{array}$ & $\begin{array}{l}\text { Volunteering experience will look } \\
\text { good on my resume. }\end{array}$ & $\begin{array}{l}\text { not at all } \\
\text { important/accurate } \\
\text { to extremely } \\
\text { important/accurate }\end{array}$ \\
\hline
\end{tabular}




\section{4-H Youth Volunteer Retention in Science Projects}

\section{Data Collection}

The request for survey participants was emailed via listserv to 4-H state program leaders, science and science, engineering and technology specialists, and members of the National Association of Extension 4-H Agents. The researcher also employed snowball sampling, a nonprobability sampling technique where existing study subjects help identify other subjects from among their colleagues, to identify and contact 4-H citizen science program leaders because there was no official designation of citizen science programing within the organization. The final strategy for identifying 4-H citizen science programs was searching social media for \#citizenscience and \#4H hashtags then contacting the 4-H professionals about the programs featured in posts.

Data were collected by paper survey and by Qualtrics survey software in May and June of 2018 from participants in six 4-H science programs in three states: Tennessee, Louisiana, and Virginia. Surveys were administered by $4-\mathrm{H}$ agents instructed by email. This research was approved by the Institutional Review Board of the LSU AgCenter. Parental consent was given at the time of the youth's enrollment in 4-H and youth assent was requested at the beginning of the survey.

\section{Data Analysis}

Data were analyzed using SPSS Version 25 statistical software. Missing data were coded as 99, a value that cannot occur as a real data value in any of the construct responses. The first objective was descriptive; frequency and percent were reported for all responses. Objectives two, three, and four were correlations. Pearson correlation coefficients were computed to determine relationships between two quantitative variables. Spearman's rank-order correlations were run between two variables where at least one was measured on an ordinal scale. For the independent sample $t$-tests, the $p$ value was set at $p=.008$ because six different $t$-tests were conducted. Race/ethnicity was also coded as non-White (0) and White (1) for independent $t$ test analysis.

\section{Results}

Descriptive information about the study participants' responses to all six constructs of the VFI and the five measures of participation have been described in Table 2. A Cronbach's alpha of 0.7 and above is generally viewed as an indicator of a reliable scale, although Kline (1999) 
notes lower values can be expected when dealing with psychological constructs like engagement. Participants reported high motivational scores across all six functions with Values, motivation related to altruistic and humanitarian purpose, having the highest mean score ( $M=$ $5.08, S D=1.67)$. Participants reported a mean dosage of 3.88 hours and intensity of 3.61 times per week of involvement in their science program. Almost all youth reported their participation in the $4-\mathrm{H}$ science program increased $(55.1 \%, n=98)$ or stayed the same $(41.6 \%$, $n=72)$ in the last 12 months.

\section{Retention}

On average, 4-H participants had positive responses indicating agreement when asked questions about feeling connected to their program (AC) and if they planned to continue volunteering in the next 12 months (ICV; see Table 2).

Table 2: Descriptive Statistics for Motivation, Participation and Retention Measures

\begin{tabular}{|c|c|c|c|c|}
\hline & $n$ & $M$ & $S$ & Cronbach's alpha \\
\hline Motivation & & & & .99 \\
\hline Values & & 5.08 & 1.67 & \\
\hline Understanding & & 5.03 & 1.73 & \\
\hline Career & & 4.93 & 1.79 & \\
\hline Enhancement & & 4.85 & 1.80 & \\
\hline Social & & 4.68 & 1.85 & \\
\hline Protection & & 4.63 & 1.89 & .47 \\
\hline Participation & & & & .63 \\
\hline Dosage & 167 & 3.88 & 6.69 & .93 \\
\hline Intensity & 168 & 3.61 & 4.24 & \\
\hline Duration & 176 & 6.13 & 3.34 & .89 \\
\hline Behavioral engagement & 179 & 3.30 & 0.53 & \\
\hline Emotional engagement & 176 & 3.22 & 0.62 & \\
\hline Cognitive engagement & 178 & 3.22 & 0.73 & \\
\hline Retention & & & & \\
\hline Affective commitment & 175 & 3.61 & 1.09 & \\
\hline Intention to continue volunteering & 177 & 2.81 & 0.93 & \\
\hline
\end{tabular}




\section{4-H Youth Volunteer Retention in Science Projects}

\section{Motivation and Retention}

Results of Pearson correlations indicated there was a positive relationship between all six motivational constructs and participant's affective commitment and intention to continue volunteering (see Table 3). The strongest correlation was between the functional motivation enhancement, that centers on the growth and development of an individual's ego, and the intention to continue volunteering $(r[173]=.78, p<.01)$.

Table 3. Correlations of Participants' Motivations and Retention as Measured by Affective Commitment (AC) and Intention to Continue Volunteering (ICV)

\begin{tabular}{|l|c|c|}
\hline & AC & ICV \\
\hline AC & & \\
\hline ICV & $.75^{* *}$ & $.71^{* *}$ \\
\hline VFI Protection & $.69 * *$ & $.68^{* *}$ \\
\hline VFI Values & $.65^{* *}$ & $.71^{* *}$ \\
\hline VFI Career & $.65^{* *}$ & $.69^{* *}$ \\
\hline VFI Social & $.66^{* *}$ & $.67^{* *}$ \\
\hline VFI Understanding & $.71^{* *}$ & $.78^{* *}$ \\
\hline VFI Enhancement & $.68^{* *}$ & \\
\hline
\end{tabular}

$* * p<0.01$ (2-tailed)

\section{Participation and Retention}

Results from Pearson's correlations between all three dimensions of engagement-behavioral, emotional, and cognitive-and the two predictors of retention showed significant positive relationships between all the variables (see Table 4). Notably, cognitive engagement is strongly correlated with both affective commitment $(r[173]=.75, p<.01)$ and intention to continue volunteering $(r[173]=.72, p<.01)$. Pearson's correlations found no significant relationship between duration, intensity, and dosage and retention measures.

Results of the Spearman correlation indicated that there was a significant positive association between consistency and the retention measures of Affective Commitment, $\left(r_{5}[171]=.353, p<\right.$ $.01)$ and Intention to Continue Volunteering $\left(r_{s}[173]=.277, p<.01\right)$. In other words, as youths' consistency of participation increases, so does the probability of their retention. 
Table 4: Correlations of Participant's Behavioral (BE), Emotional (EE), and Cognitive Engagement (CE) and Their Affective Commitment (AC) and Intention to Continue Volunteering (ICV)

\begin{tabular}{|l|c|c|c|c|c|}
\hline & AC & ICV & BE & EE & CE \\
\hline AC & & $.75^{* *}$ & $.39 * *$ & $.67 * *$ & $.75^{* *}$ \\
\hline ICV & & & $.35 * *$ & $.63 * *$ & $.72 * *$ \\
\hline
\end{tabular}

\section{Demographics and Retention}

Independent sample $t$-test were conducted. There was a significant difference in the scores for intention to continue volunteering between girls $(M=3.03, S D=.72)$ and boys $(M=2.61, S D$ $=1.06), t(160.73)=3.08, p=.002$. No statistically significant difference was found between Whites and non-Whites. Program characteristics-whether a 4-H program was science or citizen science-did have a significant relationship with both measures of retention (see Table 5), indicating that 4- $\mathrm{H}$ science programs have a higher probability of retaining members than $4-\mathrm{H}$ citizen science programs.

Table 5: Independent Sample t-tests between 4-H Science and 4-H Citizen Science Program and Affective Commitment (AC) and Intention to Continue Volunteering (ICV)

\begin{tabular}{|l|c|c|c|c|c|}
\hline \multirow{2}{*}{$\begin{array}{c}\text { Retention } \\
\text { measure }\end{array}$} & \multicolumn{2}{|c|}{ Citizen science } & \multicolumn{2}{|c|}{ Science } & \\
\cline { 2 - 6 } & M & SD & M & SD & t-test \\
\hline AC & 3.16 & 1.10 & 3.76 & 1.04 & $-3.94 * * *$ \\
\hline ICV & 2.36 & .90 & 2.97 & .90 & $-3.30 * * *$ \\
\hline
\end{tabular}

$* * * p<.001$

\section{Conclusions, Implications and Recommendations}

The lack of literature on youth volunteer retention in citizen science projects inspired this exploration of the relationships between 4-H youth participants' volunteer motivation, participation, and their retention in science projects. Notably, there was no difference in retention of White and non-White youth in 4-H science programs despite a considerably diverse participant body. The difference in retention was based on characteristics of the 4-H program itself. Results suggest citizen science programs, defined by their component of contribution to 


\section{4-H Youth Volunteer Retention in Science Projects}

generating new scientific knowledge, were less likely to retain youth volunteers than traditional 4-H science programs. Another key finding of this study is that emotional and cognitive engagement in the program are strongly correlated with retention.

The retention of non-White participants, coupled with the finding that girls have a higher reported intention to continue volunteering, is promising. Research shows that volunteering is associated with $27 \%$ higher odds of employment (Spera et al., 2013) and that African American and Hispanic workers remain underrepresented in the STEM workforce (Funk \& Parker, 2018). If $4-\mathrm{H}$ and other youth science and citizen science programs can retain female and non-White participants, those youth may enter the STEM talent pipeline.

\section{Implications for Practitioners}

Youth educators can develop retention strategies based on the evidence from this study to recruit, involve, and recognize participants and plan meaningful programming that engages youth. Recruitment messages should appeal to the motivations (understanding and enhancement) found to be strongly correlated with predictors of retention. Phrases such as "learn something new," "a chance to use skills and abilities often unused," or "put skills to use" will appeal to individuals motivated to learn and improve skills (understanding). Individuals motivated to volunteer in order to boost self-esteem and feel needed (enhancement) may respond better to messaging that includes phrases such as "we need you" or "you are needed" to call for them to become involved in the program.

Contrary to expectations, this study found evidence of a relationship between only two of five dimensions of participation-consistency and engagement-and the predictors of retention. It is possible that these results are due to the fact that $4-\mathrm{H}$ is a national organization with program standards based on best practices in youth development, and therefore the 4-H science and citizen science programs participating in this study did not differ in the other three participation variables: duration, intensity and dosage. Considering these findings, youth educators can examine how their program recognizes and rewards youth involvement. One possible strategy is for programs to recognize consistency of youth's participation instead of, or in addition to, the duration of participation in months and years or in volunteer hours. Also, youth educators should acknowledge and encourage youth when they demonstrate engagement in the program, for example, by expressing emotions such as interest and enjoyment or feelings of belonging (emotional engagement) or demonstrating a willingness to go beyond basic requirements to learn a skill (cognitive engagement) (Bohnert et al., 2010). 


\section{4-H Youth Volunteer Retention in Science Projects}

Youth educators should try to boost retention by providing opportunities for strengthening social relationships through social interactions in science and citizen science programs. Consider projects that require teamwork to accomplish the scientific goal. Youth educators should also intentionally choose to participate in citizen science programs that provide feedback from a lead scientist or prompt reporting of results, both of which have been shown to sustain volunteer participation in projects (Crimmins et al., 2014; West \& Pateman, 2016).

Only a longitudinal study can determine what factors are correlated with actual retention. Youth educators must collaborate with researchers to conduct research on retention if they want answers. The research will be complete only when it is in the hands of those that can use it.

\section{Suggestions for Future Research}

The initial intention of this research was to study 4- $\mathrm{H}$ youth participating in citizen science projects. However, accessing this population proved difficult because (a) there was no centralized listing, (b) many 4-H agents and other practitioners were not familiar with the term "citizen science," and (c) some 4-H citizen science programs have their own evaluations and did not want to oversaturate the youth with surveys.

These barriers to research of youth participation in citizen science have been noted by other researchers. They may account for the limited literature about the impacts of citizen science participation for youth in both formal and informal settings. It highlights the need for such research to continue to be conducted despite the hardships of identifying and assessing youth participants.

In fact, the inability to access enough 4-H youth participating in citizen science to sustain this study created an opportunity for comparison between 4-H science and citizen science programming participants that led to one of this study's most important findings: 4-H science programs have a significantly higher likelihood of retaining participants than 4-H citizen science programs. One hypothesis for the difference in retention between the two groups may be that youth in 4-H science programs were more socially motivated than youth in 4-H citizen science programs (Del Bianco, 2018).

This research extends our limited empirical research on youth volunteer retention and adds to the growing body of knowledge of citizen science volunteer retention. In light of the evidence of 
a correlation between consistency and engagement previously described in Del Bianco (2018), the association of youth's consistency and engagement in participation and retention should be investigated. Engagement has been called the "missing link in organized activity research" (Bohnert et al., 2010) and is where future research and assessment should be focused.

\section{References}

Allen, N. J., \& Meyer, J. P. (1990). The measurement and antecedents of affective, continuance and normative commitment to the organization. Journal of Occupational Psychology, 63(1), 1-18. https://doi.org/10.1111/j.2044-8325.1990.tb00506.x

Bohnert, A., Fredricks, J., \& Randall, E. (2010). Capturing unique dimensions of youth organized activity involvement: Theoretical and methodological considerations. Review of Educational Research, 80(4), 576-610. https://doi.org/10.3102/0034654310364533

Bonney, R., Cooper, C. B., Dickinson, J., Kelling, S., Phillips, T., Rosenberg, K. V., \& Shirk, J. (2009). Citizen science: A developing tool for expanding science knowledge and scientific literacy. BioScience, 59(11), 977-984. https://doi.org/10.1525/bio.2009.59.11.9

Chacón, F., Gutiérrez, G., Sauto, V., Vecina, M. L., \& Pérez, A. (2017). Volunteer functions inventory: A systematic review. Psicothema, 29(3), 306-316.

Champine, R. B., \& Johnson, S. K. (2017). Towards the promotion of positive development among boys in challenging contexts: A mixed-methods study of engagement in the Scoutreach initiative. Journal of Youth Development, 12(4), 16-37. https://doi.org/10.5195/jyd.2017.521

Clary, E. G., Snyder, M., Ridge, R. D., Copeland, J., Stukas, A. A., Haugen, J., \& Miene, P. (1998). Understanding and assessing the motivations of volunteers: A functional approach. Journal of Personality and Social Psychology, 74(6), 1516. https://doi.org/10.1037/0022-3514.74.6.1516

Crimmins, T. M., Weltzin, J. F., Rosemartin, A. H., Surina, E. M., Marsh, L., \& Denny, E. G.(2014). Focused campaign increases activity among participants in nature's notebook, a citizen science project. Natural Sciences Education, 43(1), 64-72. https://doi.org/10.4195/nse2013.06.0019

Curtis, V. (2015). Motivation to participate in an online citizen science game: A study of Foldit. Science Communication, 376), 723-746. https://doi.org/10.1177/1075547015609322

Del Bianco, V. (2018). Citizen science in 4-H: Youth volunteer motivations, participation, retention and scientific literacy [Unpublished doctoral dissertation]. Louisiana State University. https://digitalcommons.Isu.edu/gradschool dissertations/4751/

Eisinga, R., Teelken, C., \& Doorewaard, H. (2010). Assessing cross-national invariance of the threecomponent model of organizational commitment: A six-country study of European university faculty. Cross-Cultural Research, 44(4), 341-373. https://doi.org/10.1177/1069397110370932 
Follett, R., \& Strezov, V. (2015). An analysis of citizen science based research: Usage and publication patterns. PloS one, 10(11), e0143687. https://doi.org/10.1371/journal.pone.0143687

Frensley, T., Crall, A., Stern, M., Jordan, R., Gray, S., Prysby, M., Newman, G., Hmelo-Silver, C., Meloor, D., \& Huang, J. (2017). Bridging the benefits of online and community supported citizen science: A case study on motivation and retention with conservation-oriented volunteers. Citizen Science: Theory and Practice, 2(1), 4. http://doi.org/10.5334/cstp.84

Funk, C., \& Parker, K., January 2018. Women and men in STEM often at odds over workplace equity. Pew Research Center. https://www.pewresearch.org/social-trends/2018/01/09/women-and-men-instem-often-at-odds-over-workplace-equity/

Kline, P. (1999). The handbook of psychological testing ( $2^{\text {nd }}$ ed.). Routledge.

Li, Y., \& Lerner, R. M. (2013). Interrelations of behavioral, emotional, and cognitive school engagement in high school students. Journal of Youth and Adolescence, 42(1), 20-32.

\section{https://doi.org/10.1007/s10964-012-9857-5}

Mahoney, J. L., Vandell, D. L., Simpkins, S., \& Zarrett, N. (2009). Adolescent out-of-school activities. Handbook of adolescent psychology, 2, 228-269. https://doi.org/10.1002/9780470479193.adlpsy002008

Martin, V. Y., Christidis, L., \& Pecl, G. T. (2016). Public interest in marine citizen science: Is there potential for growth?. BioScience, 66(8), 683-692. https://doi.org/10.1093/biosci/biw070

McDougle, L. M., Greenspan, I., \& Handy, F. (2011). Generation green: Understanding the motivations and mechanisms influencing young adults' environmental volunteering. International Journal of Nonprofit and Voluntary Sector Marketing, 16(4), 325-341.. https://doi.org/10.1002/nvsm.431

Newton, C., Becker, K., \& Bell, S. (2014). Learning and development opportunities as a tool for the retention of volunteers: A motivational perspective. Human Resource Management Journal, 24(4), 514-530. https://doi.org/10.1111/1748-8583.12040

Raddick, M. J., Bracey, G., Gay, P. L., Lintott, C. J., Murray, P., Schawinski, K., Szalay, A. S., \& Vandenberg, J. (2009). Galaxy zoo: Exploring the motivations of citizen science volunteers. Astronomy Education Review, 9(1). https://doi.org/10.3847/AER2009036

Rotman, D., Hammock, J., Preece, J., Hansen, D., Boston, C., Bowser, A., \& He, Y. (2014, March 4-7). Motivations affecting initial and long-term participation in citizen science projects in three countries [Paper presentation]. iConference 2014 Proceedings (p. 110-124). https://doi.org/10.9776/14054

Seymour, V., \& Haklay, M. H. (2017). Exploring engagement characteristics and behaviours of environmental volunteers. Citizen Science: Theory and Practice, 2(1), 5. 
Journal of Youth Development | http://jyd.pitt.edu/ | Vol. 16 Issue 4 DOI 10.5195/jyd.2021.1004 4-H Youth Volunteer Retention in Science Projects

Spera, C., Ghertner, R., Nerino, A., \& DiTommaso, A. (2013). Volunteering as a pathway to employment: Does volunteering increase odds of finding a job for the out of work? Office of Research \& Evaluation, Corporation for National and Community Service, Office of Research and Evaluation. https://americorps.gov/sites/default/files/evidenceexchange/FR 2013 VolunteeringasaPathwayto Employment 1.pdf

van der Wal, R., Sharma, N., Mellish, C., Robinson, A., \& Siddharthan, A. (2016). The role of automated feedback in training and retaining biological recorders for citizen science. Conservation Biology, 30(3), 550-561. https://doi.org/10.1111/cobi.12705

West, S. E., \& Pateman, R. M. (2016). Recruiting and retaining participants in citizen science: What can be learned from the volunteering literature? Citizen Science: Theory and Practice. https://doi.org/10.5334/cstp.8 